\title{
Microstructure and phase composition of ZHS32 superalloy after selective laser melting, vacuum heat treatment and hot isostatic pressing
}

\author{
A. V. Zavodov ${ }^{\dagger}$ N. V. Petrushin, D. V. Zaitsev \\ †zavodovad@gmail.com
}

FSUE “All-Russian scientific research institute of aviation materials” RF SRC, Radio str. 17, 105005, Moscow, Russia

Using transmission electron microscopy (TEM) method, the microstructure and phase composition of nickel based superalloy ZHS32 processed by selective laser melting (SLM) of a powder composition on a monocrystalline substrate and their evolution during heat treatment (HT) and hot isostatic pressing (HIP) by different regimes have been studied. Particular features of the microstructure formed during SLM, the distribution of chemical elements in cells and their boundaries have been explored. It has been established that the material after SLM has a unidirectional heterophase cell structure consisting of the matrix $\gamma$-solid solution, nanosized $\gamma^{\prime}$-phase particles and a fine carbide phase at the cell boundaries. The influence of the HT and HIP temperature on the morphology and sizes of $\gamma^{\prime}$-phase particles, the distribution of alloying elements between $\gamma^{\prime}$ - and $\gamma$-phases, the evolution of chemical composition, the type, size and distribution of carbide precipitates in the volume and boundaries of the cells after SLM have been studied. It has been shown that the alloy contains fine ( $\mathrm{Ta}, \mathrm{Nb}$ ) $\mathrm{C}$ carbides with sizes up to $150 \mathrm{~nm}$ and carbides with sizes up to $1 \mu \mathrm{m}$, and (W, Cr) based carbides of the same sizes as well. The HIP process led to a formation of stacking faults on the phase boundaries between the $\gamma$-matrix and carbides. HT and HIP of SLM processed alloy ZHS32 has been shown to allow for obtaining a microstructure and phase composition typical for the single crystal alloy.

Keywords: nickel base superalloy, selective laser melting, microstructure, $\gamma^{\prime}$-phase, carbides, transmission electron microscopy, heat treatment, hot isostatic pressing.

\section{Микроструктура и фазовый состав жаропрочного сплава ЖС32 после селективного лазерного сплавления, вакуумной терми- ческой обработки и горячего изостатического прессования}

\author{
Заводов А. В. ${ }^{\dagger}$, Петрушин Н. В., Зайцев Д. В. \\ ФГУП «Всероссийский научно-исследовательский институт авиационных материалов», \\ ул. Радио 17, 105005, Москва, Россия
}

\begin{abstract}
Методом просвечивающей электронной микроскопии (ПЭМ) проведены исследования эволюции микроструктуры и фазового состава жаропрочного никелевого сплава ЖС32, полученного методом селективного лазерного сплавления (СЛС) порошковой композиции сплава на монокристаллической подложке, в процессе термической обработки (ТО) и горячего изостатического прессования (ГИП) по различным режимам. Изучены особенности формирующейся при СЛС микроструктуры и распределение химических элементов по ячейкам и их границам. Установлено, что материал после СЛС имеет однонаправленную ячеистую гетерофазную структуру, состоящую из матричного $\gamma$-твёрдого раствора, наноразмерных частиц $\gamma^{\prime}$-фазы и дисперсных карбидных фаз, образовавшихся на границах ячеек. Исследовано влияние температуры ТО и ГИП на морфологию и размеры частиц $\gamma^{\prime}$-фазы, распределение легирующих элементов между $\gamma^{\prime}$ - и $\gamma$-фазами, эволюцию химического состава, типа, размера и распределения карбидных выделений в объеме и на границе ячеек сплава после СЛС. Установлено, что в сплаве присутствуют как дисперсные карбиды типа (Ta, Nb) C - размером до 150 нм, так и карбиды размером до 1 мкм, а также карбиды на основе W и Cr того же размера. Операция ГИП приводит к появлению дефектов упаковки, располагающихся на границах между карбидами и $\gamma$-матрицей. Установлено, что ТО и ГИП сплава ЖС32, полученного методом СЛС, позволяют получить микроструктуру и фазовый состав, типичные для этого сплава в монокристаллическом состоянии.
\end{abstract}

Ключевые слова: жаропрочный никелевый сплав, селективное лазерное сплавление, микроструктура, $\gamma^{\prime}$-фаза, карбиды, просвечивающая электронная микроскопия, термическая обработка, горячее изостатическое прессование. 


\section{1. Введение}

Жаропрочный никелевый ренийсодержащий сплав ЖС 32 с интерметаллидно-карбидным упрочнением [1], созданный в начале 80-х годов прошлого столетия в ВИАМ, нашел широкое применение для производства методом направленной кристаллизации турбинных лопаток с монокристаллической структурой для авиационных газотурбинных двигателей.

Вследствие неравновесных условий направленной кристаллизации, приводящей к сегрегации легирующих элементов в пределах дендритных ячеек, монокристаллические отливки из сплава ЖС 32 характеризуются значительной химической и структурной неоднородностью [2]. В монокристаллических отливках из сплава ЖС 32 размер и форма упрочняющих частиц $\gamma^{\prime}$-фазы значительно различаются в дендритах и междендритных областях, в последних - частицы $\gamma^{\prime}$-фазы значительно крупнее, чем в осях дендритов. В междендритных участках монокристалла залегают выделения неравновесной эвтектики $\gamma^{\prime}+\gamma$ (или перитектической $\gamma^{\prime}$-фазы) в количестве до $5 \%$ (объемн.). Применение высокотемпературной гомогенизирующей термической обработки позволяет в значительной степени устранить дендритную сегрегацию легирующих элементов и сформировать равномерную периодичную микроструктуру материала турбинных лопаток, обеспечивающую их длительную работоспособность. Однако устранить полностью сегрегацию одного из основных легирующих элементов - рения не удается из-за его низкой диффузионной подвижности, что является одной из причин образования ТПУ-фаз в процессе длительного воздействия высоких температур $[3,4]$.

Применение метода селективного лазерного сплавления (СЛС), являющегося одним из перспективных технологических процессов изготовления изделий для авиационной и других отраслей промышленности [5-7], позволяет существенно снизить сегрегационную неоднородность материала изделий из жаропрочных сплавов.

Основной объем исследований в данной области посвящен изготовлению методом СЛС материалов, имеющих поликристаллическую структуру [8-16]. Однако возможности технологии СЛС позволяют производить «наращивание» материала не только непосредственно на платформе построения, но и на специальную подложку [17]. В этом случае особый интерес вызывает получение материала на монокристаллической подложке, имеющей определенную кристаллографическую ориентировку [18]. Исследования в данном направлении позволят развивать аддитивные технологии как для восстановительного ремонта турбинных лопаток из жаропрочных никелевых сплавов, так и для их производства.

Цель настоящей работы - установление закономерности формирования микроструктуры и фазового состава жаропрочного никелевого сплава ЖС32, полученного методом СЛС, и влияния термической обработки и горячего изостатического прессования (ГИП) на структурно-фазовые характеристики сплава.

Работа выполнена в рамках развития комплексного научного направления 2.1. «Фундаментально-ориенти- рованные исследования» («Стратегические направления развития материалов и технологий их переработки на период до 2030 года») [19].

\section{2. Объекты и методы}

Объектом исследования служили образцы жаропрочного никелевого сплава ЖС 32 , полученные в установке лазерного сплавления металлических порошков EOS M 290 методом СЛС порошковой композиции этого сплава. В таблице 1 представлен номинальный химический состав использованного сплава ЖС 32.

Подложкой, на которой проводили сплавление порошковой композиции сплава, служили полированные поверхности цилиндрических монокристаллов из того же сплава ЖС 32 , выращенные методом направленной кристаллизации в аксиальном кристаллографическом направлении $<111>$. Процесс селективного лазерного сплавления происходил в среде аргона (высший сорт) с нагревом подложки. На рис. 1 приведено изображение одного из полученных методом СЛС образцов из сплава ЖС 32 на монокристаллической подложке.

После СЛС образцы сплава ЖС32 были подвергнуты отжигу в вакууме при температурах $T_{1}$ и $T_{2}$ (где $T_{1}=T_{\text {n.p. }}, T_{2}=T_{1}-20, T_{\text {n.p. }}-$ температура полного растворения $\gamma^{\prime}$-фазы в матричном $\gamma$-твердом растворе) и ГИП при температуре $T_{1}$ в течение 4 часов.

Исследование микроструктуры выполняли методом просвечивающей электронной микроскопии на электронном микроскопе Tecnai G2 F20 S-TWIN. Локальный химический анализ проводили при помощи приставки энергодисперсионного микроанализа Oxford $\mathrm{X}-\mathrm{Max}^{\mathrm{N}} 80 \mathrm{~T}$.

Табл. 1. Химический состав сплава ЖС32 (масс. \%). Table 1. Chemical composition of alloy ZHS32 (wt. \%).

\begin{tabular}{|c|c|c|c|c|c|c|c|c|c|c|}
\hline $\mathrm{Ni}$ & $\mathrm{Cr}$ & $\mathrm{Al}$ & $\mathrm{Mo}$ & $\mathrm{W}$ & $\mathrm{Co}$ & $\mathrm{Re}$ & $\mathrm{Ta}$ & $\mathrm{Nb}$ & $\mathrm{C}$ & $\mathrm{B}$ \\
\hline осн. & 4,9 & 5,9 & 1,1 & 8,4 & 9,0 & 4,0 & 4,1 & 1,6 & 0,12 & 0,016 \\
\hline
\end{tabular}

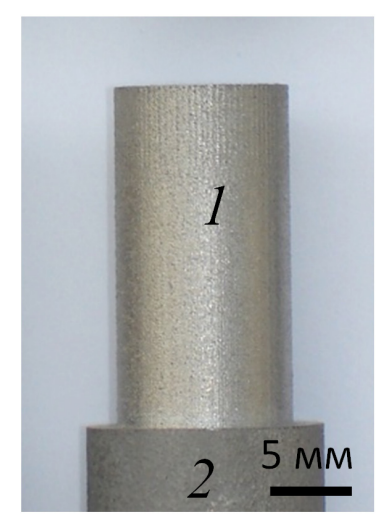

Рис. 1. Образец (1) сплава ЖС32, сплавленный на монокристаллической подложке (2) с аксиальной кристаллографической ориентацией $<111>$.

Fig. 1. Sample (1) of superalloy ZHS32 melted up on the single crystal substrate (2) with crystallographic axial orientation $<111>$. 


\section{3. Результаты и обсуждение}

\section{1. Состояние сплава после СЛС}

Микроструктура сплава ЖС32 в образцах после СЛС состоит из столбчатых ячеек с размером в поперечных сечениях примерно 0,5-0,7 мкм (рис. 2a,b). На границах ячеек наблюдаются фазовые выделения, идентифицированные как карбиды схожего химического состава. Вблизи границ ячеек и на частицах карбидов присутствуют сплетения дислокаций, появление которых может быть вызвано релаксацией упругих искажений, образовавшихся в результате роста карбидов [20]. В объеме ячеек дислокации присутствуют в меньшей степени, характерной для недеформированного литого материала.

Профиль распределения химических элементов в карбидных выделениях, полученный методом рентгеноспектрального микроанализа показан на рис. 3. В состав карбидов входит в основном ниобий, тантал и хром с небольшими добавками вольфрама, молибдена и рения. При этом соотношение легирующих элементов в карбидных частицах изменяется в зависимости от их морфологии и размера. Наблюдаемое повышенное содержание никеля в карбидных частицах объясняется тем, что при сканировании исследуемых частиц электронный луч захватывает и саму никелевую матрицу. Также обнаружено неоднородное распределение алюминия по сечению ячейки, проявляющееся повышением его содержания при переходе от центра к границам ячейки.

После СЛС сплава в ячейках микроструктуры выявлены мелкодисперсные частицы упорядоченной $\gamma^{\prime}$-фазы размером до 10 нм (рис. 2c).

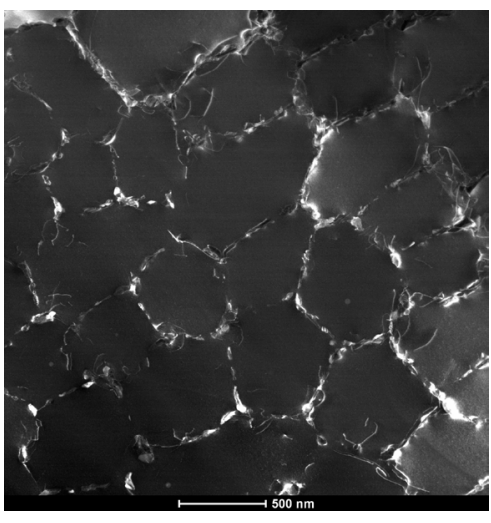

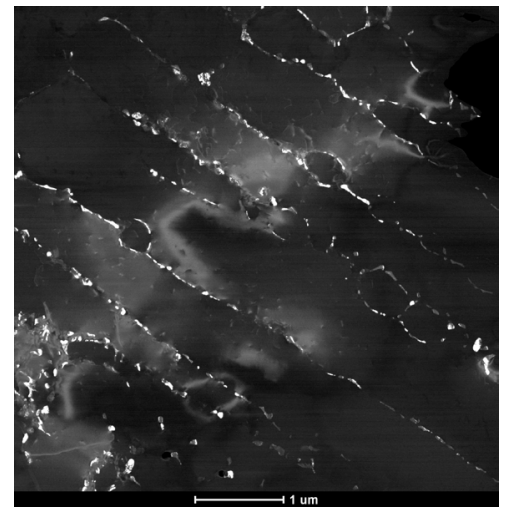

b

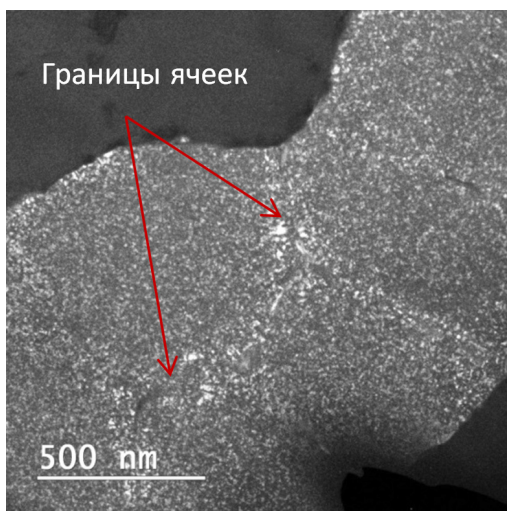

Pис. 2. Ячеистая структура образца сплава ЖС32 после СЛС с выделениями карбидов на границах ячеек (темнопольные изображения в ПЭМ): поперечное сечение ячеек (a); продольное сечение ячеек (b); наноразмерные выделения $\gamma^{\prime}$-фазы в объеме ячеек (c).

Fig. 2. Cell structure with carbide precipitates on the cells boundary of ZHS32 alloy after SLM (TEM darkfield image): transverse section of cell (a); longitudinal section of cells (b); nanosize precipitates of $\gamma^{\prime}$-phase within cells (c).
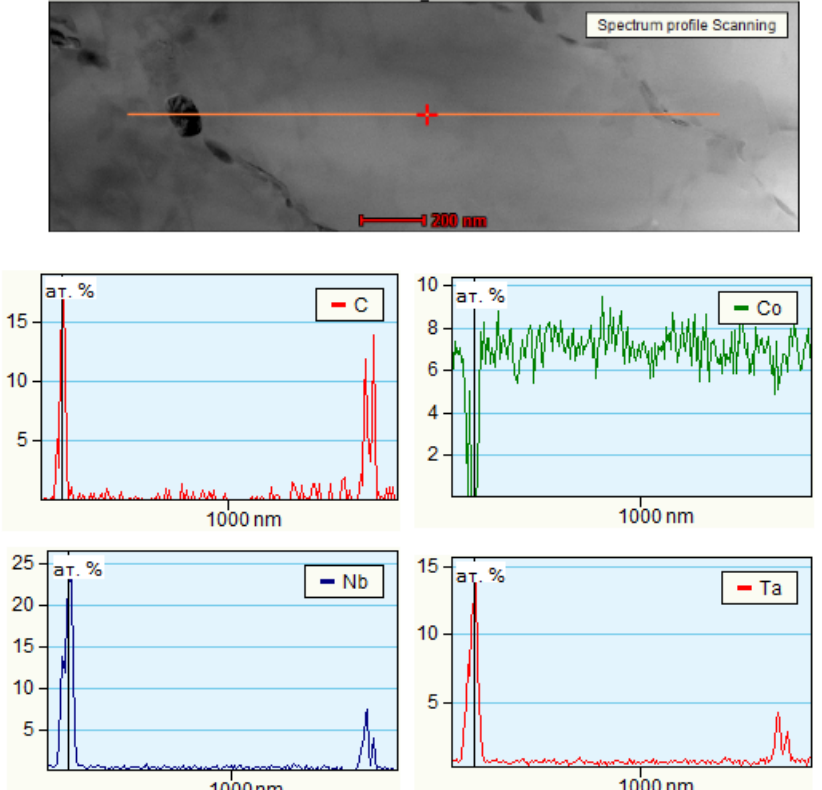

$1000 \mathrm{~nm}$

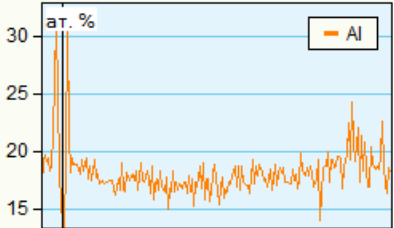

$1000 \mathrm{~nm}$
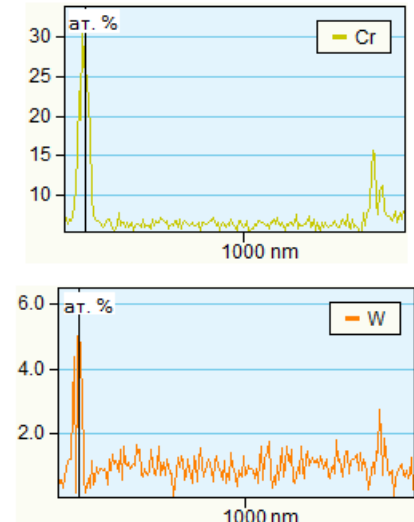

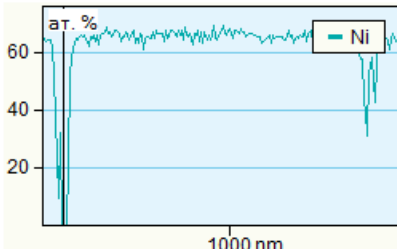

$1000 \mathrm{~nm}$
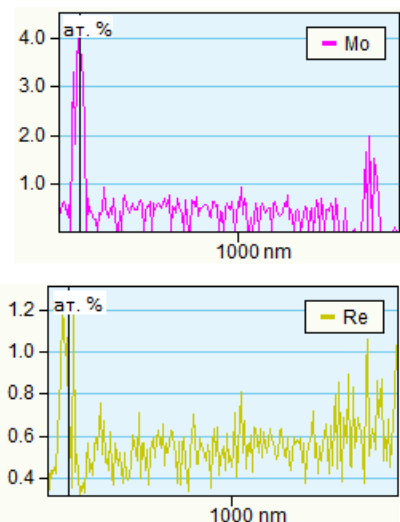

Рис. 3. Распределение химических элементов в карбидных частицах, расположенных на границах ячеек, сплава ЖСз2 после СЛС.

Fig. 3. Chemical elements distribution within cells and their boundaries. ZHS32 alloy after SLM (vertical axis — atomic \%, horizontal — nm). 


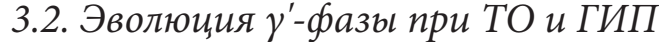

При наложении термообработки в структуре СЛС-образцов из сплава ЖС32 наблюдается рост частиц $\gamma^{\prime}$-фазы до размеров 0,2-1 мкм (рис. 4). В случае выдержки при температуре $T_{2}$ формируются частицы неправильной формы с рваными краями (рис. 4a). После выдержки при температуре $T_{1}$ частицы $\gamma^{\prime}$-фазы со средним размером 0,5 мкм приобретают кубовидную форму с более гладкими межфазными границами (рис. 4b), близкую к форме $\gamma^{\prime}$-частиц, образующихся при термической обработке монокристаллов из сплава ЖС32.

В обоих образцах в прослойках матрицы наблюдаются мелкие выделения третичной $\gamma^{\prime}$-фазы. Формирование таких частиц происходит при охлаждении сплава вследствие снижения предела растворимости легирующих элементов в $\gamma$ твердом растворе.

При наложении на исходные сплавленные образцы ГИП при температуре $T_{1}$ морфология и размеры частиц $\gamma^{\prime}$-фазы остаются такими же, что и после термообработки при той же температуре. Присутствуют как крупные частицы, близкие к кубоидным, так и мелкие выделения $\gamma^{\prime}$-фазы в прослойках. Отличие состоит в том, что в структуре появляются дефекты упаковки (отмечено стрелками на рис. 5a), образование которых связано с реакцией

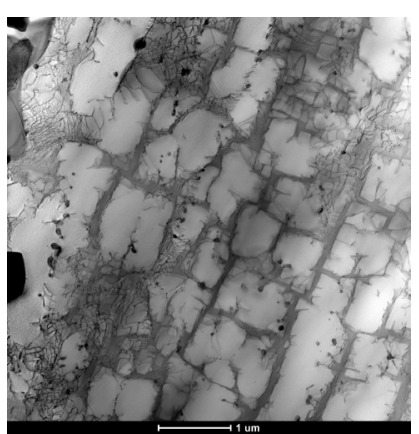

a

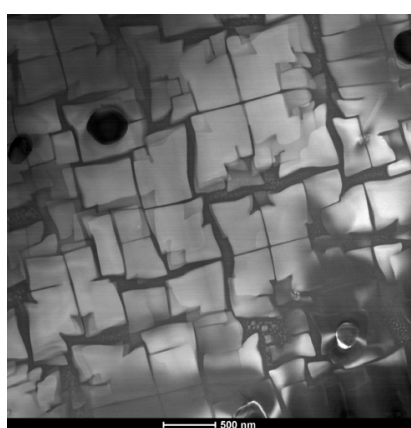

b
Рис. 4. Микроструктура сплава ЖС 32 после СЛС и ТО при температурах $T_{2}$ (a) и $T_{1}$ (b).

Fig. 4. Microstructure of ZHS32 alloy after SLM subjected $T_{2}$ (a) and $T_{1}$ (b) vacuum heat treatment.

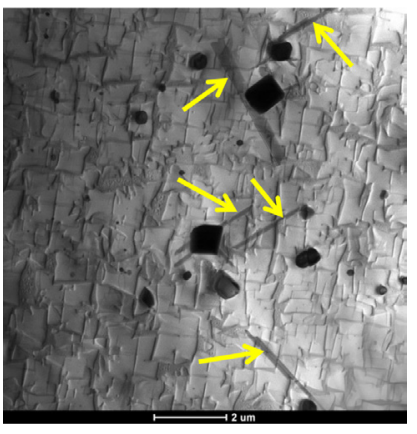

a

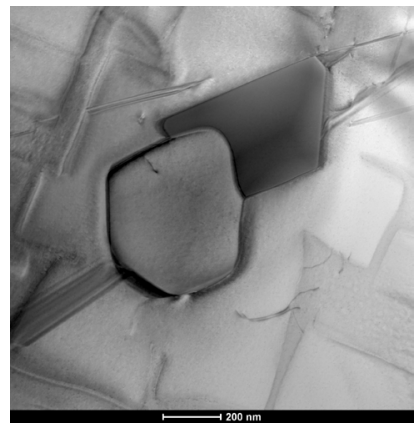

b
Pис. 5 Микроструктура сплава ЖС32 после СЛС и ГИП при температуре $T_{1}$ : (a) дефекты упаковки; (b) карбид типа (Та, $\mathrm{Nb})$ C (светлый) и карбид на основе $\mathrm{W}$ и $\mathrm{Cr}-$ (темный).

Fig. 5. Microstructure of ZHS32 alloy after SLM, HIP at $T_{1}$ : (a) stacking faults; (b) carbide (Ta, $\mathrm{Nb}$ ) C (bright) and carbide based on $\mathrm{W}$ and $\mathrm{Cr}-$ (dark). материала на приложенную баротермическую нагрузку. Дефекты упаковки образуются в плоскостях типа $\{111\}$ и проходят насквозь через частицы $\gamma^{\prime}$-фазы и матричные $\gamma$-прослойки, но останавливаются на карбидах, не перерезая их. С другой стороны, исходя из часто наблюдаемого совместного расположения дефектов упаковки и карбидных частиц, зарождение и продвижение дефектов упаковки может начинаться от границ между матрицей и карбидом. По-видимому, этим можно объяснить расположение дефектов упаковки с обеих сторон частицы карбида. Дефект упаковки под влиянием внешнего напряжения зарождается на границе между карбидом и матрицей, и распространяется по всем эквивалентным направлениям типа $<110>$.

После проведения последовательно отжига и изостатической обработки СЛС-образцов из сплава ЖС32 в их структуре формируются частицы $\gamma^{\prime}$-фазы кубоидной формы с размерами от 0,3 до 0,5 мкм и гладкими краями. Результаты картирования методом РСМА показывают обогащение $\gamma$-матрицы хромом, кобальтом и рением и в небольшой степени вольфрамом и молибденом. Кубоиды $\gamma^{\prime}$-фазы содержат алюминий.

\section{3. Анализ выделений карбидных частии,}

После каждого из исследуемых состояний сплава был проведен рентгеноспектральный микроанализ выделившихся карбидов. Обнаружено, что частицы различной морфологии и размера отличаются по химическому составу. Все наблюдаемые частицы карбидов, образовавшиеся после СЛС и различных термообработок, можно разделить на три вида.

Первый вид карбидов (вид 1 в табл. 2) наблюдается в образцах непосредственно после СЛС и после отжига при температуре $T_{2}$ (рис. 2a,b, 4a). Эти карбиды характеризуются размерами от 30 до 150 нм. В исходных сплавленных образцах эти карбиды располагаются в виде сетки по границам ячеек (рис. 2 a,b). Образование карбидов на границах ячеек является следствием неравномерного распределения углерода и карбидообразующих элементов по объему ячейки во время кристаллизации материала при СЛС. В состав таких карбидов входят почти все легирующие элементы, что обусловлено двумя причинами. Во-первых, за время процесса сплавления при быстром охлаждении не успевают произойти существенные диффузионные процессы, которые привели бы к большой разнице в составе между матрицей и карбидами. И, во-вторых, из-за небольшого размера самих карбидов рентгеновский спектр при микроанализе формируется не только частицами карбидов, но и материалом матрицы.

Подробный анализ рентгеновских спектров совместно со светлопольными изображениями ПЭМ позволяет утверждать, что видимое повышенное содержание кобальта, хрома и вольфрама в карбидах частично обусловлено расположением карбидов на межфазных границах $\gamma / \gamma^{\prime}$ и в самих прослойках $\gamma$-твердого раствора, обогащенного указанными элементами. Карты распределения химических элементов, полученные с обоих образцов, выявляют различие между карбидами до и после (рис. 6) 
термообработки. После СЛС в карбидах помимо тантала и ниобия действительно содержится хром и вольфрам (рис. 3). Интенсивность от остальных элементов, наблюдаемая на рентгеновских спектрах, относится к матрице. В карбидах после термообработки произошло перераспределение химических элементов и небольшой рост частиц. В результате чего карбиды содержат только тантал и ниобий (рис. 6). Анализ дифракционных картин от карбидов первого вида даёт период кристаллической решетки (кубическая гранецентрированная), равный 0,438 нм, что соответствует карбидам состава (Ta, Nb)C.

Второй вид карбидов (вид 2 в табл. 2), наблюдаемых во всех состояниях после ГИП и отжигов при разных температурах, представляет собой относительно крупные (до 1 мкм) огранённые частицы карбида на основе тантала и ниобия. Результаты анализа дифракционных картин, полученных от таких карбидов, позволяют утверждать, что кристаллическая решетка частиц кубическая гранецентрированная с периодом 0,443-0,447 нм. Согласно данным базы PDF в такой диапазон значений периодов попадают карбиды состава $(\mathrm{Nb}, \mathrm{Ta}) \mathrm{C}$ и $\mathrm{NbC}$, что согласуется с полученными результатами РСMА.

К третьему виду карбидов относятся карбиды с большим содержанием вольфрама (от 20 до 30 ат. \%), хрома (от 8 до 30 ат. \%) и молибдена. Остальные легирующие элементы содержатся в них в количестве не более 10 ат. \%. Размеры частиц - до 1 мкм. Период кристаллической решетки этих карбидов составляет 1,13 нм, что соответствует карбидам со стехиометрией $\mathrm{Cr}_{23} \mathrm{C}_{6}$, в которых часть хрома замещена вольфрамом. Стоит заметить, что размер и морфология карбидов двух последних видов практически не отличаются, поэтому визуально, без РСМА и наблюдения дифракционных картин, разделить эти карбиды не представляется возможным (рис. 5b).

\section{4. Выводы}

1. Сплав ЖС32, полученный методом СЛС на монокристаллической подложке с кристаллографической ориентировкой $<111>$, имеет ячеистое строение и состоит из однонаправленных ячеек, по границам которых рас- полагаются карбиды состава (Ta, Nb)C, как в виде непрерывных выделений, так и отдельных частиц размером до 150 нм.

2. Упрочняющая $\gamma^{\prime}$-фаза в материале после СЛС присутствует в виде наноразмерных частиц. При проведении последующей термической обработки и ГИП формируются типичные для жаропрочных сплавов кубоиды $\gamma^{\prime}$-фазы, идеальность формы которых зависит от температуры выдержки.

3. После отжига при температуре $T_{2}$ и ГИП в структуре сплава присутствуют два вида карбидов: карбиды $(\mathrm{Ta}, \mathrm{Nb}) \mathrm{C}$ размером до 1 мкм и карбиды, формирующиеся на основе $\mathrm{W}$ и $\mathrm{Cr}$ того же размера, близкие по стехиометрии к $\mathrm{Cr}_{23} \mathrm{C}_{6}$ с частичным замещением хрома вольфрамом.

Табл. 2. Содержание металлических элементов в карбидах.

Table 2. Content of metal elements in carbide particle.

\begin{tabular}{|c|c|c|c|c|c|c|c|c|c|c|}
\hline \multicolumn{1}{|c|}{ Содержание элементов, ат. \% / Element content, at. \% } \\
\hline Вид & $\mathrm{Ni}^{*}$ & $\mathrm{Al}$ & $\mathrm{Cr}$ & $\mathrm{Mo}$ & $\mathrm{W}$ & $\mathrm{Co}$ & $\mathrm{Re}$ & $\mathrm{Ta}$ & $\mathrm{Nb}$ \\
\hline \multicolumn{8}{|c|}{ После СЛС / After SLM } \\
\hline 1 & 30 & 12 & 16 & 2 & 5 & 5 & 0,7 & 7 & 11 \\
\hline \multicolumn{7}{|c|}{ После ТО при температуре $T_{1} /$ After HT at temperature $T_{1}$} \\
\hline 2 & - & - & - & - & - & - & - & 47 & 30 \\
\hline 3 & 8 & 5 & 15 & 7 & 30 & 10 & 3 & 2 & 5 \\
\hline После ТО при температуре T/ / After HТ at temperature $T_{2}$ \\
\hline 1 & 28 & 8 & 5 & 0,4 & 3 & 9 & 0,2 & 6 & 7 \\
\hline 2 & - & - & 2 & - & - & 1 & - & 40 & 30 \\
\hline \multicolumn{7}{|c|}{ После ГИП / After HІР } \\
\hline 2 & - & - & 2 & - & - & - & - & 55 & 27 \\
\hline 3 & 7 & 9 & 15 & 7 & 18 & 10 & 1,5 & 2 & 4 \\
\hline \multicolumn{7}{|c|}{ После ТО + ГИП / After HТ + НІР } \\
\hline 2 & - & 2 & 1 & - & - & 2 & - & 50 & 30 \\
\hline 3 & - & 8 & 19 & 7 & 25 & 8 & 3 & 2 & 6 \\
\hline
\end{tabular}

* содержание никеля в карбидах частично обусловлено перекрытием частиц с матрицей / nickel content in carbides is partly due to the overlapping of particles with matrix
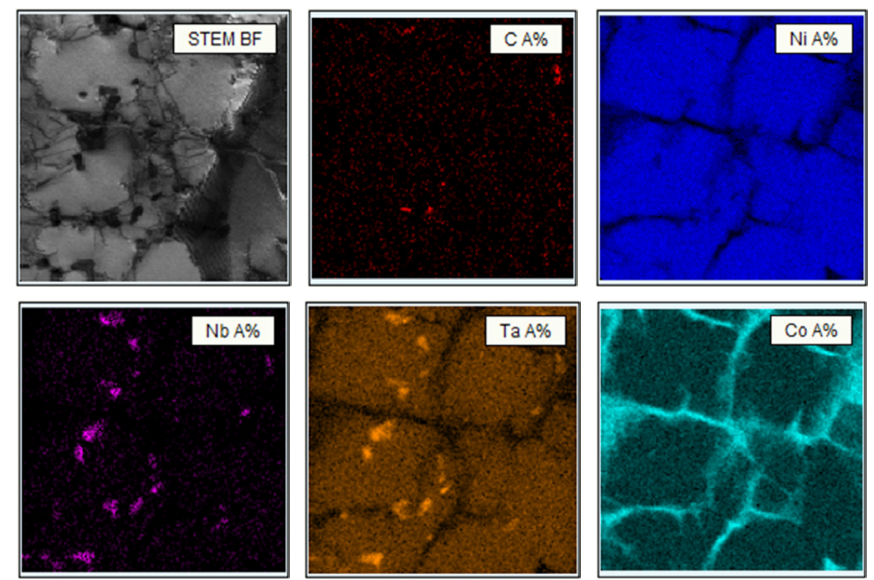
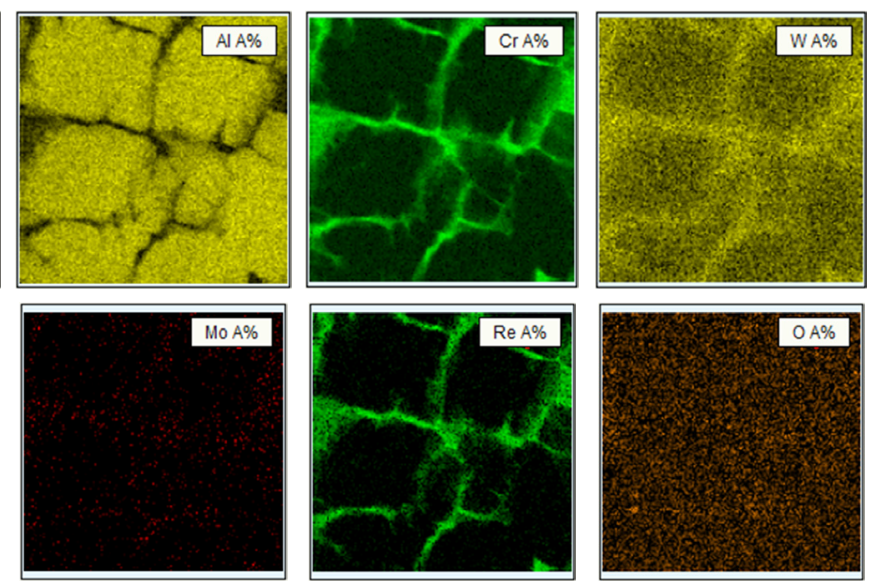

Рис. 6. Распределение химических элементов по $\gamma, \gamma^{\prime}$ фазам и карбидам сплава ЖС32 после СЛС и ТО при температуре $T_{2}$. Fig. 6. Chemical elements distribution within $\gamma$ and $\gamma^{\prime}$ phase, and carbides of ZHS32 alloy after SLM and heat treatment at $T_{2}$. 
Благодарность/Acknowledgements. Авторский коллектив выражает благодарность Российскому научному фонду за предоставленный грант № 15-19-00164, в рамках которого была сделана настоящцая работа.

\section{Литература/References}

1. Кишкин С.Т., Каблов Е.Н. Литейные жаропрочные сплавы для турбинных лопаток // В сб. Авиационные материалы. Избранные труды «ВИАМ» 1932-2002. М.: ВИАМ. 2002. С. 48-58.

2. Петрушин Н.В., Висик Е.М., Горбовец М.А., Назаркин Р. М. Структурно-фазовые характеристики и механические свойства монокристаллов жаропрочных никелевых ренийсодержащих сплавов с интерметаллидно-карбидным упрочнением // Металлы. 2016. № 4. С. $57-70$.

3. Каблов Е. Н., Светлов И. Л., Петрушин Н. В. Никелевые жаропрочные сплавы для литья лопаток с направленной и монокристаллической структурой (часть II) // Материаловедение. 1997. № 5. С. 14-17.

4. Пигрова Г.Д., Рыбников А.И. Карбидные фазы в сплаве ЖС-32 // Металловедение и термическая обработка металлов. 2013. № 12 (702). C. 21-23. (Pigrov a G.D. Rybnikov A.I. Carbide Phases in Alloy ZhS-32. Metal Science and Heat Treatment. 2014, Vol. 55, 11. P. $658-659$.)

5. Каблов Е.Н. Физико-химические и технологические особенности создания жаропрочных сплавов, содержащих рений //Вестник Московского университета. Серия 2: Химия. 2005. Т. 46. № 3. С. $155-167$.

6. Каблов Е.Н. Из чего сделать будущее? Материалы нового поколения, технологии их создания и переработки - основа инноваций //Крылья родины. 2016. № 5. C. $8-18$.

7. Каблов Е.Н. Аддитивные технологии - доминанта национальной технологической инициативы. // Интеллект и технологии. 2015. № 2 (11). С. 52 - 55.

8. Суфияров В.Ш., Попович А.А., Борисов Е.В., Полозов И.А. Селективное лазерное плавление титанового сплава и изготовление заготовок деталей газотурбинных двигателей //Цветные металлы. 2015. № 8. C. $76-80$.

9. Евгенов А. Г., Горбовец М. А., Прагер С. М. Структура и механические свойства жаропрочных сплавов ВЖ159 и ЭП648, полученных методом селективного лазерного сплавления //Авиационные материалы и технологии. 2016. № S1 (43). С. 8 - 15.

10. Евгенов А.Г., Рогалев А.М., Неруш С.В., Мазалов И.С. Исследование свойств сплава ЭП648, полученного методом селективного лазерного сплавления металлических порошков //Труды ВИАМ. 2015. № 2. Ст.02. URL: http://www.viam-works.ru (дата обращения 23.03.2016). DOI: 10.18577/2307-6046-201 5-0-2-2-2.
11. Trosch T., Ströbner J., Völkl R., Glatzel U. Microstructure and mechanical properties of selective laser melted Inconel 718 compared to forging and casting // Materials Letters. 2016. Vol. 164. P. $428-431$.

12. Jia Q., Gu D. Selective laser melting additive manufacturing of Inconel 718 superalloy parts: Densification, microstructure and properties // J. Alloys and Compounds. 2014. Vol. 585. P. $713-721$.

13. Лукина Е.А., Базалеева К.О., Петрушин Н.В. Цвет кова Е.В. Особенности формирования структуры жаропрочного никелевого сплава ЖС6К-ВИ при селективном лазерном плавлении // Цветные металлы. 2016. № 3 (879). C. $57-62$.

14. Лаптева М.А., Белова Н.А., Раевских А.Н., Филонова Е.В. Исследование зависимости шероховатости, морфологии поверхности и количества дефектов структуры от мощности лазера, скорости сканирования и типа штриховки в жаропрочном сплаве, синтезированном методом СЛС // Труды ВИАМ. 2016. № 9 (45). URL: http://www.viam-works.ru (дата обращения 12.01.2017). DOI: 10.18577/2307-6046-2016-0-9-9-9.

15. Суфияров В.Ш., Попович А.А., Борисов Е.В., Полозов И.А. Селективное лазерное плавление жаропрочного никелевого сплава. // Цветные металлы. 2015. № 1. C. $79-84$.

16. Carter L. N., Wang X., Read N., Khan R., Aristizabal M., Essa K., Attallah M. M. Process optimization of selective laser melting using energy density model for nickel based superalloys // Materials Science and Technology. 2016. Vol. 32. Iss. 7. P. $657-661$. http://dx.doi.org/10.1179/17 43284715Y.0000000108.

17. Basak A., Acharya R., Das S. Additive manufacturing of single-crystal superalloy CMSX-4 through scanning laser epitaxy: computational modeling, experimental process development, and process parameter optimization // Metallurgical and Materials Transactions A. 2016. Vol. 47. No. 8. P. $3845-3859$.

18. Евгенов А. Г., Лукина Е. А., Королев В. А. Особенности процесса селективного лазерного синтеза применительно к литейным сплавам на основе никеля и интерметаллида $\mathrm{Ni}_{3} \mathrm{Al} / /$ Новости материаловедения. Наука и техника. 2016. № 5 (23). С. 3 - 11.

19. Каблов Е.Н. Инновационные разработки ФГУП «ВИАМ» ГНЦ РФ по реализации «Стратегических направлений развития материалов и технологий их переработки на период до 2030 года» // Авиационные материалы и технологии. 2015. № 1. С. 3-33. DOI: 10.1 8577/2071-9140-2015-0-1-3-33.

20. Sundararaman M., Mukhopadhyay P., Banerjee S. Carbide precipitation in nickel superalloys 718 and 625 and their effect on mechanical properties // The Minerals, Metals \& Materials Society. 1997. P. $367-378$.

21. Masoumi F., Shahriari D., Devaux A. Kinetics and mechanism of $y^{\prime}$ reprecipitation in a Ni-based Superalloy // Scientific Reports. 2016. 6.iDoi: 10.1038/srep28650. 